\title{
Libel Regulatory Analysis
}

\author{
Martin M. Shapiro†
}

Whenever lawyers and journalists gather to talk about hibel, inevitably the first amendment becomes a center of attention. I would not dream of denying its central place in that debate. Nor do I forget that journalists, and the corporations for which they work, have, at the very least, the same freedom-of-speech rights as the rest of us and perhaps more. It is an old academic trick, however, to take a problem that is commonly viewed from one perspective and instead view it from another. Such a switch im perspectives may sometimes lead to ideas and conclusions that would otherwise escape us. Thus, purely for analytical purposes, I would like to begin by considering hibel solely froin the perspective of government regulation of industry, completely leaving out first amendment perspectives. Obviously iny imtention is not to shight constitutional protections but only to see if the news industry might learn something from the kinds of regulatory analysis that commentators apply to laws regulating other industries.

The much heralded and denounced "explosion" of tort law, whether seen as a greater propensity to sue or a propensity to award higher damages, has taught all of us that tort law is not purely private law that governs only the relations between private persons. It is also public law, an integral part of the regime of government regulation of private enterprise. Thus we may treat hibel law as a problem of government regulation of industry and, for the moment, the media as an industry and journalism as a profession. If we do that, we can see why there is so much concern with libel. We live in an era of extensive government regulation of industry. The media are a large industry so we grapple for law to regulate that industry. A number of factors have led people to want more law regulating the media industry. One of the most basic reasons is concentration. There are fewer major daily newspapers than there used to be, and so each is more powerful, particularly in its own local reader area. The three network television news shows, through which an enormous number of persons gain their daily exposure to the news, represent that same kind of concentration. Increases in concentration inevitably lead to increased interest $\mathrm{m}$ regulation. With or without the general tort

$\dagger$ Professor of Law, Boalt Hall School of Law, University of California, Berkeley. B.A., 1955, University of California, Los Angeles; Ph.D., 1961, Harvard. 
law explosion, we could have expected an increase in libel regulation in a news industry that appears to be more and more concentrated.

There are also certain special characteristics of the electronic and the print media that lead to more interest in regulation. For the electronic media, the special characteristic is, of course, dramatic nuance. We are much more afraid of television commentators than we are of newspaper writers, because newspaper writers cannot inject the tone, the turn of head, the grin, that television journalists can. Television people have an enormous power of msinuation that is more difficult for print media people to exercise. This power inakes us inore afraid of them and more willing to regulate them by hel law and in other ways.

Two special characteristics of newspapers attract regulatory interest. One is their new geographic scope. The New York Times is delivered to doorsteps all over America. The Los Angeles Times is now the major paper in an area that runs from Santa Barbara to Bakersfield to the Mexican border. Moreover, these and other megapapers have adopted a format that signals increased danger to many of us. Most of the front page of the New York Times and the L.A. Times and many other big newspapers consists of by-lined stories. The by-lined story tends to confuse the distinction between editorial comment and news reporting. In general, the mixture of opinion and news has become much more intimate and much more subtle than in the old days when papers printed mostly simple, unsigned, fact stories on the front page and then extreine hyperbole on the editorial page. Today's by-hined newspaper, written by investigatory reporters practicing pubhic-interest journalisin, so melds facts and interpretation that it constitutes a far graver threat to reputation than did the older style of journalism.

The complaint one hears from journalists is the complaint that one hears from any industry. We wish we didn't have laws governing us; we'd rather get on with our own affairs. True enough, but this is a very large industry that poses various probleins to the public. It is likely to get regulated. The howl that journalists raise about libel law is the howl that all professionals raise about being subject to law, but this is a society in which we subject professionals to more and nore law. And indeed, journahsts often support the extensions of law to other professions. So, leaving to others the first amendment analysis of libel, let ine turn to libel simply as a body of law that functions to regulate an industry and a profession.

Let me focus upon the reckless-disregard standard of New York Times $v$. Sullivan. This standard would fail to provide a satisfactory regulatory framework because it creates perverse incentives. It provides

1. 376 U.S. 254 (1964). 
incentives to the regulated industry to perform as badly as possible. If a newspaper is liable only if it has engaged in reckless disregard, a standard measured by normal journalistic practice, then there is a strong incentive, in an mdustry that already has other mcentives in that direction, to do the worst possible work. The worse work you do, the less it can be shown that what you do on any given day is in reckless disregard. ${ }^{2}$ A standard that moves an industry toward bad practice is a bad regulatory standard. Thus leaving aside any question of freedom of the press, a regulatory analysis suggests reform of this standard.

Another thing that makes reckless disregard a bad regulatory standard is the phenomenon that we see at the end of some of the lawsuits in which it is applied. The newspaper or television company wins because it has not engaged in reckless disregard. The jury finds that although what the journalist said was false, it did not involve reckless disregard. As everyone charges out the courtliouse door to their TV interviews, the defendant's lawyer, revved up by his adversary enthusiasm says, "We won. We have been vimdicated." And the message that "we won" tends to obliterate the principal vindication the individual plaintiff miglit have attained. Not only doesn't he get any money, he doesn't draw much public attention to the fact that what was said about him was false. Thus, the reckless-disregard standard is a bad standard because it tends to obscure the truth/falsehood issue and is ill tailored to aclieve one miportant regulatory goal, preventing injury to individuals through falsehoods.

Finally, a reckless-disregard standard, or even a neghigence standard, may be criticized from yet another regulatory perspective. Perforinance standards are frequently preferable to process standards. ${ }^{3}$ Under a perforinance standard, the regulated industry is told what its end product must be, not what processes for producing that product it must employ. Auto manufacturers are told that their fleets of new cars must attain an average gas consumption of thirty miles to the gallon. They are not told that they must reach this goal by producing a higher ratio of small-to-large cars, or by reducing car weiglit, or by mcreasing engine efficiency. They may choose any mix of these they choose. High pollution industries may switch to producing a new product, change their manufacturing process, change their fuel, or install scrubbers im

2. Neither Time Inc. v. Hill, 385 U.S. 374 (1967) nor Associate Press v. Walker, 388 U.S. 130 (1967) explicitly condone sloppy journalistic practices, but both suggest that customary practice, such as whether or not sources are ordinarily rechecked, will be taken into account in determining whether a failure to engage in those pracatices in a particular instance will be considered reckless disregard. 385 U.S. at 395-96; 388 U.S. at 130.

3. See, e.g., Breyer, Analyzing Regulatory Failure: Mismatches, Less Restrictive Alternatives and Reform, 92 HARV. L. REv. 549, 573 (1979) (performance standards encourage development of new technology). 
their smoke stacks, so long as they produce $x$ amount less smoke. The obvious advantages of performance or output standards is that they require less government intervention in the internal affairs of the industry, and they place more of the decisions in the hands of those with the greatest experience and expertise.

The New York Times reckless-disregard standard is, of course, a process standard. It requires a high degree of government (in this instance, the judicial part of government) intervention into the internal processes of news gathering to determine whether there was reckless disregard in a particular instance. Furthermore, if common law works the way it is supposed to, over time the reckless-disregard cases should generate a set of judicially declared standards for news gathering as courts tell us what journalistic practices are and are not reckless. A strict-liability-truth standard on the other hand is an output standard. The government will not care how you arrive at a good news product, so long as you arrive at one. All other things being equal, therefore, the news industry ought to prefer the strict-hability-truth standard.

One great advantage of this performance standard may be seen if we reintroduce the first amendment for a moment. The media have been striving for some years to create a first amendment right to government nonintrusion in the newsroom. One of the major barriers to the creation of such a right is the patent unfairness of requiring a public figure plaintiff to prove reckless disregard while forbidding that plaintiff to use compulsory process to ferret out what went on in the reporting process. By using a process standard, the Court has created for itself the paradox that the law it invented to protect critics of public figures now makes them subject to a degree of intrusiveness in their news gathering and writing process that they might otherwise have avoided.

This point might be especially relevant to the problem of pretrial costs that has been haunting the media. The reckless-disregard standard serves as the foundation for dragnet-style discovery demands. Who knows what scrap of conversation or paper will reveal the stone left unturned that proves reckless disregard of truth. As a practical matter, a shift from reckless-disregard- to strict-liability-truth might or might not, by itself, reduce the severity of discovery demands very much. ${ }^{4}$ But it would clear the way to a first amendment claim to protection against draguet discovery, just as it would clear the way for the same kind of claims against intrusion by subpoena at the trial stage.

Ultimately, of course, the problem with substituting a performance standard of truth for a process standard of reckless disregard is that the

4. Professor Franklin believes that it would. Franklin, A Declaratory Judgment Alternative to Current Libel Law, 74 CALIF. L. REv. 809, 828-30 (1986). 
performance standard may simply be too high for the industry to meet or at least to prove that it has met. I take it that few journalists would want to argue that truth was too high a standard. Their concern would be with "chilling effect," and "breathing space." Held to a very high standard of performance, whose achievement was difficult to prove, the media might shy away from important stories that they were convinced were true but appeared to be particularly difficult to prove to a judge and/or jury. This problem would be further aggravated where reporting incited hostile community sentiment.

These problems may already have been reduced to acceptable levels, however, by shifting the burden of proof. For historical reasons now largely irrelevant, truth was a "defense" in a libel action, and so the burden of pleading and proving it was on the speaker. ${ }^{5}$ But, the Supreme Court shifted the burden of proof to the public official who, even without the reckless-disregard test, must still prove that the speech is false. ${ }^{6}$

A final practical question is whether a truth standard would further reduce the number of pretrial judgments granted to media defendants and/or up the ante on pretrial settlements. With the burden of proof shifted as it has been, I would guess that the media would not be worse off in these respects than now. But I am not qualified to make even a good guess. I must leave that to others.

I think it follows from the arguments that I have made that the media might be attracted by Professor's Franklin's proposal. His restoration action provides a package of a particularly high burden on plaimtiff to prove falsity and an abandonment of reckless disregard in favor of strict liability. It provides a mode of government regulation in which the industry can correct its errors at relatively low cost and with relatively low levels of government incursion. It may also reduce discovery burdens. ${ }^{7}$ While the Franklin proposal serves as an addendum to the New York Times standard and so does not eliminate its basic regulatory pathologies, it would alleviate those pathologies somewhat by shifting many disputes away from the reckless-disregard standard.

Whether or not the particular proposals I have made appear attractive, I hope what I have said here is at least modestly persuasive on the most basic point. The media are a major industry and one that appears to pose some problems for the public interest. As a result, they cannot hope to escape from some measure of regulation. Like all other regulated industries, the media ought to learn how to do their own regulatory anal-

5. See M. Frankin, Cases and Materials on Mass Media LaW, $98-99$ (1982 2d ed.).

6. Cox Broadcasting Corp. v. Cohn, 420 U.S. 469, 490 (1975).

7. The central aspects of Professor Franklin's proposals concerning when and what level of damages and legal fees might be collected under strict-liability and reckless-disregard standards raise issues that go well beyond the rather modest point $I$ am making here. 
ysis because surely lots of other people are going to be doing such analysis and advocating media regulation from their conclusions. By their very nature, the media ought to be attracted to performance as opposed to process standards and seek to build media regulations by combining performance standards with first amendment considerations. 